\title{
Affirmative Religious Response Culture to HIV and AIDS: Understanding the Public Relations Role of JAKIM in Curbing the Epidemic among Young Muslim Couples in Malaysia
}

\author{
Tham Jen Sern ${ }^{1} \&$ Hasmah Zanuddin ${ }^{1}$ \\ ${ }^{1}$ Department of Media Studies, University of Malaya, Malaysia \\ Correspondence: Tham Jen Sern, Department of Media Studies, University of Malaya, Malaysia. E-mail: \\ jstham87@gmail.com
}

Received: January 2, 2014 Accepted: April 25, 2014 Online Published: June 25, 2014

doi:10.5539/ass.v10n13p8 URL: http://dx.doi.org/10.5539/ass.v10n13p8

\begin{abstract}
In regards to containing the spread of the deadly disease namely HIV/AIDS, it is particularly troublesome that the culture of information sharing in terms of sexuality still remains as a private subject and taboo for discussion not only among the Muslim communities but among the Asian communities as well. Despite the fact that Islam is concerned in placing a high value on chaste behaviour, prohibiting sexual intercourse outside marriage and homosexuality, the HIV/AIDS infection will not suppress just because of these strict Islamic doctrines are mostly adhered by fellow Muslims. While the HIV/AIDS scourge is disastrous in disregard of the religious, signaling a dire need to understand the role of religious response in curbing the disease so as to reach out to the target audiences effectively. This study is specifically to explore the responsibility of Jabatan Kemajuan Islam Malaysia or the Malaysia Department of Islamic Development (JAKIM) in respect to how they convey the accurate information to the Muslim communities in general and among the young Muslim couples in specific. Therefore, semi-structural elite interview with the officer was conducted in order to dwell into the plight of how the religious institution addresses the epidemic. The study found that JAKIM has conferred striking benefits to the Muslim community in curtailing the spread of HIV/AIDS through its publication on "Manual on HIV/AIDS in Islam" and the Premarital HIV Screening Programme. The fantastic contribution of JAKIM therefore can maintain links between the religious group, government, media, and stakeholders on fighting the HIV/AIDS issues.
\end{abstract}

Keywords: Islam, HIV/AIDS, JAKIM, information sharing, religious institution

\section{Introduction}

Speaking of the devastating disease in the world-Acquired Immunodeficiency Syndrome (AIDS) - is replete with sensitivities especially when it comes to religious perspectives. In many cases, HIV/AIDS is always attributed by the blames of immorality, dangerous lifestyle and illegal drug use (Badri, 1997; Nelkin, 1991). In order to overcome unhealthy behaviour, religion has been instrumental as means to teach and disseminate accurate information in terms of protection and rectifying discrimination and stigmatization towards HIV/AIDS and people living with HIV/AIDS (PLHIV) to the populace. While the world gives an insight into the role played by a wide variety of religions in responsibly halting the deadly disease to its community per se, new challenges are eventually posed to the religions.

Over the span of 30 years since the first case of HIV/AIDS was identified in the United States in 1981 (Morbidity and Mortality Weekly Report [MMWR], 2001), the culture of information sharing in terms of sexuality still remains as a private subject and taboo for discussion not only among the conservative countries but among the Asian communities as well and has become particularly troublesome (Hasnain, 2005; Trinitapoli, 2009). Moreover, there are a few governments in the Muslim countries that refuse to face the relentless growth of HIV/AIDS as a threat to them (Hasnain, 2005). A bundle of researches have also reviewed through Islam's perspective, that HIV/AIDS is prone to punishment from God or viewed as a divine curse for an immoral act (Oluduro 2010: 210; Paruk, Mohamed, Patel, \& Ramgoon, 2006; Economic and Social Commission for Asia and the Pacific, 2003; Kopelman, 2002; Badri, 1997; Kitzinger, 1998). Hence, from the cursory glance at the response of Islam dealing with HIV/AIDS in the preceding discussion, it postulates that Islam is far away from 
accomplishing the mission in curtailing the HIV infection on its communities. However, how true of a statement is this? Is the religion sluggish in responding to the issue? To answer these questions, a dire need for researchers to dwell into the plight of how religious institution (in this case the JAKIM) addresses the epidemic, conveys the accurate information and rolls out a policies with regard to the epidemic to the dwellers is signaled.

Intrinsically, religion is not just a matter of paying respect to the God. Instead, it provides ethical guidelines for living and reflects one's cultural beliefs, and the cultural beliefs give substantial meaning to every aspect of an individual's life (Hasnain, 2005; Economic and Social Commission for Asia and the Pacific, 2003). Religion, in fact, has tremendous influence on addressing the disease. Toeing to that thought, a religion can be a facilitator as well as a "constraint" in the fight against HIV/AIDS. To be a facilitator, every religion asks its fellows to adhere to certain tenets like abstinence and fidelity, praying, avoiding premarital sex and extramarital sex. Such compliances are effective in helping people to change their behaviour in positive ways and conferring on protective benefits against the sexual transmission of HIV, if people adhere to it in their daily lives (Hasnain, Sinacore, Mensah, \& Levy, 2005; Gary, 2004; Ellison \& Levin, 1998; Badri, 1997). On the contrary, consistent with the traditional religious views in opposing to the use of condoms, especially in regards to warding off HIV infection during sexual intercourse can be a "constraint" in the fight against the disease. In effect, information deprivation due to lack of an open and frank discussion on the issue can result in the difficulty in preventing the spread of the disease and stemming the stigma and discrimination thereon making HIV/AIDS a "hidden" epidemic.

Despite religion having such influence, little limelight has been given to affirm the role of public relations played by religious authorities or agencies especially government-based religious agencies in responding, circulating HIV/AIDS-related messages or information and teaching at the local level. Most of the researches, indeed, focused on the role played by either religious leaders or faith-based organizations (Oluduro, 2010; Trinitapoli, 2009, 2006; Soraya Azmi, 2006; Hasnain, 2005), but as aforementioned study on government-based religious authorities still remain unexplored. Consequently, while most people agree that Islam is the traditional religion, and sexuality and HIV/AIDS issues are taboo for discussion in the region, therefore this is the inclination of the researchers to unravel, explore and affirm the responsibilities of Jabatan Kemajuan Islam Malaysia or the Department of Islamic Development Malaysia (JAKIM) on how this government-based religious agency deals with the disease, and communicates with the Muslim community effectively.

\section{HIV/AIDS in Malaysia}

As one of the world's most open economies and holding Islam as the official state religion, Malaysia is no longer coy about the claim that our communities are protected from HIV/AIDS infection due to religious and cultural norms (Olunduro, 2010). Based on the Global AIDS Response 2012, the cumulative number of reported HIV infections since the first detection in 1986 for Malaysia, by the end of 2011 was 94841 cases; 17, 686 were AIDS cases with 14986 deaths. The trend of HIV infection in Malaysia is in fact mainly attributed by injecting drug users (Malaysia 2012 Global AIDS Response Progress Report, 2012; United Nations General Assembly Special Session on HIV/AIDS for Malaysia [UNGASS], 2010). However, the trend has presently changed. Women are now the vulnerable population on contracting the HIV infection through their spouse. Furthermore, deprivation of information and refusing to talk openly about the disease among mothers cause their beloved children to also get infected through vertical transmission.

The statistics show that the number of women reported to be infected with HIV in 2011 is 735 . This figure is 67 people more compared to the number of reported HIV cases in 2010. On top of that, the number of people reported to be infected with AIDS in 2011 was also higher (203 people) than reported in 2010 (167 people). Nonetheless, the number of deaths in 2011 was slightly lower (92 people) than the figure in 2010 (122 people). Whilst children and young people aged 19 years and below made up 120 people or 3.5 per cent of 3479 newly reported HIV infection in 2011. Seriously, more than 70 per cent of people living with HIV/AIDS (PLHIV) is currently Muslims, and an article had also reported that the number of Malays getting infected with HIV is worrisome (The Star, 2010, June 9; Utusan Malaysia, 2006, December 8).

\section{Malaysian Media Coverage on HIV/AIDS}

Researches indicated that the media coverage on HIV/AIDS in Malaysia was unevenly distributed from January to June 2011 (Tham \& Zanuddin, 2011).

Table 1 shows that of all the 49 articles covered in all three selected mainstream newspapers, The Star contributed a high amount of news reporting on the disease which covered 22 articles, followed by Sin Chew Daily covered 16 articles and 11 articles for Utusan Malaysia. This explained that Malaysian media reported 
insufficient HIV/AIDS-related news towards public for educating people to well-understand about HIV and social marketing programmes that help PLHIV.

Table 1. News articles distribution according to month for year $2011(\mathrm{~N}=49)$

\begin{tabular}{lccccccc}
\hline \multicolumn{1}{c}{ Newspaper } & Jan & Feb & Mar & Apr & May & Jun & Total \\
\hline Utusan Malaysia & 3 & 0 & 3 & 2 & 3 & 0 & $\mathbf{1 1}$ \\
The Star & 3 & 3 & 3 & 2 & 6 & 5 & $\mathbf{2 2}$ \\
Sin Chew Daily & 2 & 0 & 9 & 1 & 2 & 2 & $\mathbf{1 6}$ \\
Total & $\mathbf{8}$ & $\mathbf{3}$ & $\mathbf{1 5}$ & $\mathbf{5}$ & $\mathbf{1 1}$ & $\mathbf{7}$ & $\mathbf{4 9}$ \\
\hline
\end{tabular}

Table 2. News articles distribution from Islamic perspective

\begin{tabular}{cll}
\hline No & \multicolumn{1}{c}{ Headline } & \multicolumn{1}{c}{ Date } \\
\hline 1 & $\begin{array}{l}\text { Aidiladha: 130 anak yatim, HIV/AIDS dirai [Aidiladha: 130 orphans, HIV/AIDS } \\
\text { celebrated] }\end{array}$ & 2006, January 11 \\
2 & Fakta mengenai seks oral dan perbuatan liwat [Facts of anal sex and sodomy] & 2006, February 2 \\
3 & LZS selamatkan akidah kami ["LZS saves our faith] & 2011, January 27 \\
4 & Mereka tidak berdosa [They are innocent] & 2011, April 17 \\
5 & Darul Ukhuwwah tempat berlindung [Darul Ukhuwwah place for shelter care] & 2011, June 8 \\
6 & Diskriminasi pesakit HIV [Discrimination of HIV patients] & 2011, June 14 \\
\hline
\end{tabular}

Utusan Malaysia is the most widely read Malay newspaper in Malaysia. In terms of its target audiences, Utusan Malaysia serves the Malay community in which most of them are Muslims. Table 2 shows that out of 54 articles examined from January 1, 2006 to June 30, 2006 and January 1, 2011 to June 30, 2011, only six articles reported news on HIV/AIDS from an Islamic perspective. In respect to culture of information sharing, through a cursory glance, coverage of HIV/AIDS from an Islamic point of view in Utusan Malaysia is notably left more room for improvement.

\section{What Is JAKIM?}

JAKIM is the Malay abbreviation for Jabatan Kemajuan Islam Malaysia or the Department of Islamic Development Malaysia in English. Before JAKIM was established, Bahagian Hal Ehwal Agama Islam or the Islamic Affairs Division (BAHEIS) was formed to protect the purity of faith and the teachings of Islam in Malaysia. Later, in line with the exponential growth of the country's Islamic development and progress, the Government of Malaysia decided to replace BAHEIS with JAKIM on $1^{\text {st }}$ January 1997 with reasons to mobilize the development and progress of Muslims in Malaysia (see http://www.islam.gov.my/en/about-jakim).

JAKIM is located at the Federal Territory of Putrajaya, a new Federal Government Administrative Centre for Malaysia. In line with the efforts of Malaysia in fighting against the spread of HIV/AIDS infection among the Muslim community, JAKIM is one of the Ministry of Health's strongest advocates in addressing the issue on HIV/AIDS and Islam in this region (Rahman, 2011). Therefore, JAKIM has become one of the most outstanding government-based religious agencies in track to halt the issue among its community.

\section{Policies and Strategies Implemented}

Since the first case of HIV had been detected in the Federal Territory of Kuala Lumpur in December 1986, the Malaysian government had realized that HIV/AIDS epidemic can no longer be treated as a health problem, but interrelated with culture, taboo, and sexuality of a nation. In light with the statement that claims more than 70 per cent of people living with HIV/AIDS (PLHIV) is Muslims (The Star, 2010, June 9), government, religious agencies and non-governmental organizations are facing many challenges to continue on containing the widespread of HIV infection not only towards the Muslim society but the Malaysians as a whole. While waiting the breakthrough - vaccines for HIV/AIDS, the Ministry of Health, JAKIM, state religious departments, the Malaysian AIDS Council to name a few, have worked together to provide effective, feasible and applicable strategies and intervention programmes for Malaysia to combat HIV infection. One of the holistic plans or 
programmes that helped the Muslim community and government to reduce and prevent the continuous growth of HIV/AIDS cases among the population is the Premarital HIV Screening Programme.

The first premarital HIV screening programme for Muslim couples was introduced to the people of Johor in November 2001 (Khebir, Adam, Daud, \& Shahrom, 2006). The premarital HIV screening programme, ideally, is enacted for Muslim couples who intend to wed. Virtually, the prevailing objective of premarital HIV screening programme is to allow early detection on HIV infection thereon making HIV/AIDS education available with emphasis on safety precautions after marriage, how to minimize the risk of spouse or other people contracting the disease which includes the use of condom and expedient treatment like Highly Active Antiretroviral Therapy (HAART) to the respective individuals (Khebir et al. 2006). By doing so, the government can do her best in reducing and controlling the prevalence of HIV infection among the public. However, before and during the programme is in track, a lot of reprobation about human rights and people's confidentiality was heard from the public. This posed as an extreme challenge to both the Ministry of Health and JAKIM or/and state religious departments to sustain the programme's applicability and feasibility in this context.

Aside from the premarital HIV screening programme for Muslims, former Deputy Prime Minister, Dato' Sri Najib Tun Abdul Razak (current Malaysian Prime Minister) also announced the National Strategic Plan on HIV/AIDS (NSP) in 2006 to continue in providing an appropriate balance between prevention, treatment, care and support over a five-year period from 2006 till 2010 to the general population (Ministry of Health, 2006). This plan replaced the 1998 HIV/AIDS National Strategic Plan, where the NSP was involved a range of consultative process, including a multi-sectoral consultation with the NSP, such as Non-governmental Organizations (NGOs), religious leaders, business, and community groups. This indicates that the national plan was not singularly done by the government itself but in collaboration with other parties in order to tackle the epidemic comprehensively. Nevertheless, due to the NSP 2006-2010 ended in 2010, the latest revision, the NSP 2011-2015 continuously serves the public in order to ensure common grounds and initial objectives are able to reach out to the grassroots expansively. In accordance to the former NSP 2006-2010, the balance between prevention, treatment, care and support over the five-year period will still remain substantial in terms of curtailing the HIV/ADIS scourge in this region. The objectives of the NSP 2011-2015 are showed as follows (Global AIDS Response Progress Report, 2012).

a) To further reduce by $50 \%$ the number of new HIV infections by scaling up, improving upon and initiating new and current targeted and evidence based comprehensive prevention interventions

b) To increase coverage and quality of care, treatment and support for people living with HIV and those affected

c) To alleviate the socioeconomic and human impact of AIDS on the individual, family, community and society.

d) To create and maintain a conducive and enabling environment for government and civil society to play meaningful and active roles in decreasing stigma and discrimination.

e) To further increase general awareness and knowledge of HIV, and reduce risk behaviour among the risk and vulnerable populations.

\section{Methodology}

It is well-described that asking the right person to tell us about their experience on a respective topic is rather holistic for a research. Since this study is specifically designed to unravel, discover and affirm the responsibilities played by the JAKIM in tackling the HIV/AIDS-related issues among the Muslims, semi-structured elite interview was carried out under this bulk of paper.

\subsection{Interview Procedures}

An elite interview was conducted with Mr Zakuan bin Sawai, the Chief Assistant Director (Senior) of JAKIM, in order to provide valuable information with regards to the effort contributed by the institution to the community. Due to the fact that the rule of thumb of conducting a research is completely relies on voluntary involvement, a written consent from the University was sent to the interviewee prior to the interview. Once the interviewee agreed to take part in the individual interview, an appointment was made by both the researcher and the interviewee.

\section{Findings and Discussion}

Zakuan has been dealing with the HIV/AIDS-related issues since 2008 at the Malaysian National Antidrug Agency. Although his prevailing job scope was to overcome the issue of drug use in Malaysia, there are still drug users whom are HIV Positive in this region. After he joined the JAKIM, he continuously shared his 
experience in the area of reducing and rectifying the HIV/AIDS-related stigma and discrimination to the community. He claims:

"We [JAKIM] want to tell the community to reduce stigma and discrimination towards people living with HIV. That's why we [JAKIM] produced the "Manual Islam \& HIV/AIDS" to show our effort in tackling the HIV/AIDS-related issues. We [JAKIM] want to explain to the community. We don't label "patient" for people with HIV. Instead, we call them as "people living with HIV". The same goes to drug [users]. We don't call them "drug addicts"; we call them "drug users" in order to show respect and no stigma towards these people."

\subsection{Creating Awareness and Healthy Community Culture}

In the preceding discussion, stigmatization and discrimination can be completely impeded to the people living with HIV/AIDS. Every day, these people feel social aversion which is enacted from their society. This is the result from a society having little knowledge and information about the HIV/AIDS and the people living with it as well as the complicated nature of the disease. Many people perceive people living with HIV/AIDS as a sinner. Zakuan shares:

“...Before this, when there were HIV people in the community, people discriminate them. These HIV people must be the bad guys. So, community labels them as bad guys. Indeed, these people got infected with HIV not because they are sex workers or intravenous drug users. But, some of them got HIV from their husbands especially fishermen living at the area. Their husbands go fishing, and he then gets HIV from Thai prostitutes or had transsexual activities with other fishermen during fishing trips and then he doesn't realize that he has the virus and brings and transfers it to his wife. His wife who gets the virus then transfers it to her children. He [the husband] passes away, and then his wife becomes a widow living with HIV as well as her children. That's also many [these kinds of people are pervasive indeed]. So, when the community knows, oh... this is HIV people. No! Please, they are innocent. From there, we [JAKIM] give explanation to the community leaders to help them [mothers and children with HIV], giving support, giving whatever help that they need. That's the whole, not only Muslims, but non-Muslims also are our job as they are neighbors in the community...."

As presented earlier, the HIV/AIDS transmission trend has presently changed. Mother, children and youth are now the vulnerable group in contracting the disease. Malika and Katare (2004) claimed that in order to stem the rates of HIV/AIDS transmission, education and information are indispensability, followed by prevention and control. However, in the United States, college students who are youths with a degree still have a mindset that a person can contract HIV from mosquito bites (Inungu, Mumford, Younis, \& Langford, 2009). This is proof that information in terms of precautions on HIV transmission, prevention and fostering positive behavioural change is not circulating to the grassroots, especially to youths who are effectively the hope of a nation (Tham \& Zanuddin, 2012). Hence, collaboration with other agencies in providing accurate information on HIV/AIDS to the local level is rather crucial.

\subsection{Information Distribution and Collaboration Culture}

When researchers ask the interviewee how the JAKIM plays its role in handling the HIV/AIDS issues among the young Muslims in Malaysia, Zakuan shares:

"For youths, actually, we are working with Malaysian Ministry of Youth and Sports. Due to the fact, to date, the youth has fewer figures in HIV transmission, yet we [JAKIM and the Ministry] give explanation to them in order for them to have some prevention aspects in their social life so that they would not get the disease from their friends who take drugs. However, this is not just in the Ministry of Youth but also involves the Ministry of Education, in schools. We have campaigns and talks in collaboration with the Ministry of Education; in general. Because in schools, we are unable to tackle who has HIV. But for those that we know, we have programmes to motivate them to keep their life normal, to get treatment regularly from the Ministry of Health. Do not stop their medications. And Alhamdulillah that we are also getting funds from the Ministry of Health to organize programmes for the community."

Zakuan also denotes that information provision pertaining to HIV/AIDS from the health perspective is referred to the so-called "baby" by the Ministry of Health. JAKIM is just a supportive agency in dealing with religious issues. Based on the premise, a bundle of researches have indicated and ascertained that religion does play a significant role in terms of addressing HIV/AIDS-related issues (Malaysian AIDS Council 2011; Muñoz-Laboy et al., 2011; Oluduro, 2010; Trinitapoli, 2009 \& 2006; United Nations Children's Fund [UNICEF], 2003). To Zakuan, the role of JAKIM in addressing HIV/AIDS from the religious point of view is:

“...if we live normally, guided by the religions, then the thing [HIV/AIDS] would not happen. For instance, if we take drug, [we are] not only found guilty in law, but [we] also found guilty from religious perspectives. We 
take things that have no beneficial to us. If people got HIV from promiscuity such as from sex workers or homosexual, those activities can compromise them. All those activities are prohibited in Islam. Explanation pertaining to those unhealthy activities is circulated to the Muslim community. Of course we know as a human, we give whatever explanation, sometimes the lust still exists, and they do [those unhealthy activities] as well. We have programmes to visit those sex workers, gays, and transgender at "lorong-lorong" [back street] to explain to them. The Ministry of Health does their job as well; they do prepare condoms to those people through NGOs."

\subsection{Outreach Programme and Premarital HIV Screening for Muslims}

As aforementioned, in order to help the Muslim community and the Government to reduce and prevent the continuous growth of HIV/AIDS, Premarital HIV Screening Programme was introduced. Zakuan shares:

"We have started the programme since 1986, but it was not comprehensive. Now, in 2012, the programme has reached out to all states. The last state that has recently taken part was Sarawak. Now, I can confirm that all states have the programme in track. For the young Muslim if you want to wed, you must go through the test first. But, the test is private and confidential. We [JAKIM] would not know [the information and the test results]; as it is conducted by the Ministry of Health, not us [JAKIM]. The Ministry of Health (MOH) keeps their privacy right, and the Ministry will inform the couple of their test results. They $[\mathrm{MOH}]$ also would not tell their family. For instance, if you are going to marry, both of you [fiancé and fiancée] have to go for the test. If the result is Positive, only you would know, and then discuss with your spouse whether or not to marry. We, as a religious agency, would not know because it's related to an individual's human rights. However, $\mathrm{MOH}$ will put him/her for further medical treatment. Normally couples will let JAKIM knows about the result eventually, voluntarily and ask for advice from ulama' (religious knowledgeable person at JAKIM). If the couple chose to marry, then JAKIM will advise them to discuss with their family and get their blessings before the solemnization. Some couples with HIV do get their family blessings but a few do not. And they still choose to marry despite the family opposing.

Initially, when the result is released and is found Positive, they [both couple] will then discuss with the $\mathrm{MOH}$ and to decide whether to continue the marriage. If they do then, okay, during their marriage, they are advised to wear condom whenever they have sexual intercourse. However, some of the cases happened when MOH knows that there is an individual who is HIV positive, but their child did not get infected by the virus. However, when MOH knows that there is an individual who is HIV and his wife is pregnant, $\mathrm{MOH}$ will monitor the progress of the mother and the child, and the mother will not go for normal labor, maybe she will undergo operation etc. ....If I am not mistaken, non-Muslims are also required for the test as well sooner or later. Because when the Ministry of Women, Family and Community Development sees the advantages of tracing the HIV and AIDS cases, the non-Muslims are also going to undergo HIV screening."

\subsection{News Coverage on Islamic Perspective}

Commenting on the coverage of HIV/AIDS from an Islamic perspective (see Table 2), the news stories fall short of needs and demands in regards to reaching out and being visible to the Muslim communities. While literatures reveal that most of the time information on disease condition presented by the mass media fails to provide follow-up or mobilizing information that enables people for behavioural change actions, the media could play the significant role of a critical agent to induce the positive behavioural change that can reverse the epidemic (Hoffman-Goetz, Shannon, \& Clarke, 2003). This makes sense to Malaysia which has a very vibrate media industry.

\section{Conclusion}

After looking through a cursory glance at affirming the role played by JAKIM in addressing the HIV/AIDS issues among its community, this study has now provided a small piece of the whole picture on how significant is the culture of sharing information for a religious agency in a country contains the spread of HIV/AIDS to the readers.

The publication of the "HIV \& Islam Manual" by JAKIM in which offers information pertaining to the role of religious leaders in spreading messages of HIV and AIDS awareness, principles of HIV and AIDS prevention from the perspective of Islam, and HIV and AIDS related healthcare and welfare services available has proved their efforts and concerns in responding to the issues of HIV/AIDS among the Muslim community (Malaysian AIDS Council, 2011).

On the other hand, in order to prevent youths from easily contracting HIV/AIDS and for early detection, the Premarital HIV Screening Programme which was enacted by the Ministry of Health in collaboration with JAKIM has also conferred striking benefit to the country in controlling the spread of HIV/AIDS among the 
Muslim community. Not just that, in terms of culture of information sharing pertaining to HIV/AIDS-related information to the specific audiences, JAKIM had shared the news by publishing the "HIV \& Islam Manual" in the local newspaper in order to reach out to the public and make their responsibility on HIV/AIDS salient among the public (The Star 2011, May 23).

When public health information becomes a focus among the community at large, information sharing on various public health problems beyond conveying scientific information (in this case, through culture perspective, e.g., religion) is rather needed. Within the realm of public relations, the health public relations focuses on a very specific function that captures the audience within the health environment or problems. Consequently, the fantastic work contributed by the JAKIM is in line with the appeal from the United Nations Children's Fund (2003) in prompting a nation to develop and maintain links between the religious groups, government, media, and stakeholders on fighting the HIV/AIDS issues.

\section{Acknowledgments}

Special thanks is extended to Mr. Zakuan bin Sawai, Chief Assistant Director (Senior) from the Department of Islamic Development Malaysia (JAKIM), who accepted my interview on $4^{\text {th }}$ July 2012, and shared valuable information on the religious response culture to HIV and AIDS to this bulk of paper.

\section{References}

AIDS/ATD Section Disease Control Division Ministry of Health, Government of Malaysia. (2010). 2010 UNGASS country progress report. Retrieved from http://www.moh.gov.my/c=nation

Badri, M. (1997). The AIDS crisis: An Islamic socio-cultural perspective. Kuala Lumpur: International Institute of Islamic Thought and Civilization (ISTAC).

Economic and Social Commission for Asia \& the Pacific. (2003). For good sake!: Asia-Pacific faith-based organizations battle HIV/AIDSHIV/AIDS prevention, care and support: Stories from the community. New York: United Nations Publications. Retrieved from http://www.unescap.org/publications/detail. asp?id=775.

Ellison, C. G., \& Levin, J. S. (1998). The religion-health connection: Evidence, theory, and future directions. Health Education and Behavior, 26(6), 700-720. http://dx.doi.org/10.1177/109019819802500603

Gary, P. B. (2004). HIV and Islam: Is HIV prevalence lower among Muslims? Social Science \& Medicine, 58, 1751-1756. http://dx.doi.org/10.1016/S0277-9536(03)00367-8

Hasnain, M. (2005). Cultural approach to HIV/AIDS harm reduction in Muslim countries. Harm Reduction Journal, 2(23). http://dx.doi.org/10.1186/1477-7517-2-23

Hasnain, M., Sinacore, J. M., Mensah, E. K., \& Levy, J. A. (2005). Influence of religiosity on HIV risk behaviors in active injection drug users. AIDS care, 17(7), 892-901. http://dx.doi.org/10.1080/ 09540120500038280

HIV/STI Section. (2012). Malaysia 2012 global AIDS response country progress report. Kuala Lumpur: Disease Control Division, Ministry of Health Malaysia. Retrieved from http://www.moh.gov.my/images/ gallery/Report/Cancer/UNGASS_MALAYSIA_final.2_2010-1.pdf

Hoffman-Goetz, L., Shannon, C., \& Clarke, J. N. (2003). Chronic disease coverage in Canadian Aboriginal newspapers. Journal of Health Communication: Internation Perspectives, 8, 475-488. http://dx.doi.org/10.1080/10810730390233299

Inungu, J., Mumford, V., Younis, M., \& Langford, S. (2009). HIV knowledge, attitudes and practices among college students in the United States. Jhhsa Winter, 259-277.

Jabatan Kemajuan Islam Malaysia. (2012). About Jakim. Retrived from http://www.islam.gov.my/en/aboutjakim

Khebir, B. V., Adam, M. A., Daud, A. R., \& Shahrom, C. M. D. (2007). Premarital HIV screening in Johor(2002-2004). Medical Journal of Malaysia, 62(1), 19-22.

Kopelman, L. M. (2002). AIDS and Africa. Journal of Medicine and Philosophy, 27(2), 139-142. http://dx.doi.org/10.1076/jmep.27.2.139.2991

Malaysian AIDS Council. (2011). HIV \& Islam: Responsible religious response to HIV \& AIDS in Malaysia. Retrieved from http://dl.dropbox.com/u/64663568/library/hiv-and-islam.pdf

Mallika, N., \& Katare, R. S. (2004). AIDS communication in India. Media Asia, an Asian Communication Quarterly, 31(4), 231-238. 
Ministry of Health. (2006). Malaysia National Strategic Plan on HIV/AIDS 2006-2010. Putrajaya. Retrieved from http://hivaidsclearinghouse.unesco.org/ search/resources/1329_malaysia20062010.pdf

More than $70 \%$ of AIDS/HIV sufferers in Malaysia are Muslims: AIDS Council. (2010, June 9). The Star. Retrieved from http://thestar.com.my/news/story.asp?file=/201006091514227se

Muñoz-Laboy, M., Garcia, J., Moon-Howard, J., Wilson, P. A., \& Parker, R. (2011). Religious responses to HIV and AIDS: Understanding the role of religious cultures and institutions in confronting the epidemic. Global Public Health: An International Journal for Research, Policy and Practice, 6(2), S127-S131.

Nelkin, D. (1991). AIDS and the news media. The Milbank Quarterly, 69(2), 293-307. http://dx.doi.org/10.2307/ 3350206

Oluduro, O. (2010). The role of religious leaders in curbing the spread of HIV/AIDS in Nigeria. Potchefstroom Electronic Law Journal/Potchefstroomse Elektroniese Regsblad, 13(3), 208-236.

Paruk, Z., Mohamed, S. D., Patel, C., \& Ramgoon, S. (2006). Compassion or condemnation? South African Muslim students' attitudes to people with HIV/AIDS. Journal of Social Aspects of HIV/AIDS, 3(3), 510-515. http://dx.doi.org/10.1080/17290376.2006.9724878

Rahman, H. A. (2011). Manual on HIV/AIDS in Islam. Kuala Lumpur: Department of Islamic Development Malaysia.

Soraya Azmi. (2006). The role of religious leaders in the fight against HIV/AIDS. New York: United Nations Development Programme. Retrieved from http://www.undp.org.my/uploads/Role_of_Religious_Leaders_ in_Fight_Against_HIV.pdf

Tham, J. S., \& Zanuddin, H. (2011). Reach and visibility: Perception and social marketing of AIDS patients in Malaysian media. Paper presented at the International Conference on Media and Communication (Mention 2011): Communication and Transformation: Progress and Paradox Hotel Equatorial, Bangi-Putrajaya.

Tham, J. S., \& Zanuddin, H. (2012). Coverage of HIV/AIDS in Malaysia: A case study of The Star. Malaysian Journal of Communication, 28(1), 151-169.

Trinitapoli, J. (2006). Religious responses to AIDS in Sub-Saharan Africa: An examination of religious congregations in rural Malawi. Review of Religious Research, 47(3), 253-270.

Trinitapoli, J. (2009). Religious teachings and influences on the ABCs of HIV prevention in Malawi. Social Science \& Medicine, 69, 199-209. http://dx.doi.org/10.1016/j.socscimed.2009.04.018

U.S. Department of Health and Human Services. (2001). First report of AIDS Morbidity and Mortality Weekly Report (Vol. 50, pp. 429-444): Washington, DC: Government Printing Office. Retrieved from http://www.cdc.gov/mmwr/pdf/wk/mm5021.pdf

United Nations Children's Fund. (2003). What religious leaders can do about HIV/AIDS-Action for children and young people. Retrieved from http://www.unicef.org/adolescence/ files/Religious_leaders_Aids.pdf

Alias, M. R. (2006, December 8). Bilangan Melayu hidap HIV membimbangkan [Number of Malays getting HIV is worrisome]. Utusan Malaysia, p. 12.

\section{Copyrights}

Copyright for this article is retained by the author(s), with first publication rights granted to the journal.

This is an open-access article distributed under the terms and conditions of the Creative Commons Attribution license (http://creativecommons.org/licenses/by/3.0/). 